DOI: 10.17805/trudy.2017.5.3

\title{
СЕМЬЯ И КАРЬЕРА В ЖИЗНИ СОВРЕМЕННОЙ РОССИЙСКОЙ ЖЕНЩИНЫ
}

\author{
Л. О. Ромашова, Е. М. Середа \\ Московский гуманитарный университет
}

\begin{abstract}
Аннотация: Статья посвящена извечной проблеме выбора между семьей и карьерой современной молодой женщины в условиях России. Рассматриваются проблемы совместимости профессиональной карьеры с семейными обязанностями, а также факторы, способствующие снижению семейных ценностей.
\end{abstract}

Ключевые слова: женщина; российская женщина; семья; карьера

\section{FAMILY AND CAREER IN THE LIFE OF THE MODERN RUSSIAN WOMAN}

\author{
L. O. Romashova, E. M. Sereda \\ Moscow University for the Humanities
}

\begin{abstract}
The article deals with the eternal problem of choosing between family and career by the modern young woman in Russia. It discusses the compatibility issues of professional career and family responsibilities, as well as the factors promoting decline in family values.
\end{abstract}

Keywords: woman; Russian woman; family; career

Рыночные условия, а также формирующиеся сложные социальноэкономические ситуации определяют жизненные стратегии женщин, их ценностные установки и уровень притязаний. Меняются жизненные стандарты и формируются новые интересы, определяющие уровень социального успеха в обществе. Сознательно конструируя личный путь самоопределения, женщины стоят перед выбором жизненных целей: деловая активность, характеризующая профессиональным статусом, независимостью или семейный быт, ограниченный, прежде всего, заботами о доме, семье, детях. В современном мире становится сложно гармонизировать свои потребности в рамках экономической самостоятельности из-за трудностей во взаимоотношениях с делами общественными, производственными и семейными.

Рыночные отношения во всех сферах носят противоречивый характер. С одной стороны рыночная экономика вроде бы предоставляет 
свободу и независимость, а именно - в выборе сфер приложения труда, развитии предпринимательства, изменении социального статуса, приобретении самостоятельности, реализации креативных способностей и инициативы, в общем, создаются условия для свободного самоопределения и самореализации. С другой стороны, рыночные преобразования создают противоречия, заключающиеся в асимметрии рынка труда, трансформации института семьи, роста агрессивной конкуренции, вытеснения женщин из властных структур, а также трудности использовании профессионального потенциала, роста безработицы и т. д. В связи с этим меняются и приоритеты самореализации женщины как личности. Тем не менее, наблюдается стойкая позиция у женщин в жизненных ориентациях, которая выражается в стремлении повысить свой статус, добиться успеха, признания общественностью своих деловых способностей, борьбе за власть. Вместе с тем профессиональный труд не становится самоценным для самих женщин. Стоит остро вопрос о совместимости профессиональной карьеры с семейными обязанностями.

Современные молодые женщины в настоящее время вынуждены выбирать либо карьерный рост и активную личную жизнь с обширным кругом общения, либо рождение и воспитание детей с нахождением на содержании супруга или на государственном пособии. Большинство уверены, что материнство и успешность несовместимы, вследствие этого создание семьи и рождение детей откладывается до позднего возрастного периода. По данным Роскомстата, за 2016 г., было зарегистрировано более 439000 браков с невестами, возраст которых составил 25-35 лет и более 216000 браков, где возраст невесты более 35 лет (Демография, Электр. ресурс) - соответственно $45 \%$ и $22 \%$ от общего количества зарегистрированных браков. Прослеживается тенденция поздних браков среди девушек.

Современные представления девушек и молодых женщин о семье и семейных ценностях в значительной степени влияют на будущее развитие института семьи, сказываются на предпочтении определенных форм семьи, детности, гендерных ролей, и, как следствие, на стабильность и гармонию общества, ввиду того, что семья выступает его структурной единицей и одновременно «мини-моделью».

Одним из негативных факторов, отрицательно сказывающихся на формировании у современных молодых женщин семейных ценностей, является навязывание образа «свободной женщины», которая не связана не только узами брака, но и узами отношениями с мужчиной. Причем, формирование такой модели поведения начинается еще на стадии подросткового возраста. Женщина в большей степени предпочитает общественное производство. Профессиональная работа составляет основную нагрузку современниц, а внерабочее время тратится на восстановление 
сил, сохранение и поддержание работоспособности.

Анализируя научную литературу к распространенным факторам, способствующих снижению семейных ценностей можно отнести следующие:

- падение качества жизни в стране и регионе, понижение уровня дохода на каждого члена семьи;

• слабая система социальной защиты семьи и детей;

- пропаганда поздних браков в Европе;

- ухудшение уровня культуры семьи в обществе,

- рост независимости и индивидуализма;

- приоритет эгоистических интересов над семейными;

- недостаток просветительных мер о семейной жизни;

- современное движение «чайлд-фри» и др.

- Негативное воздействие этих факторов на семейные ценности молодых женщин способствует снижению уровня активности в решении личностных проблем.

Можно также отметить, что полностью посвятить себя семье для современной женщины не всегда предоставляется возможным, в силу сложившихся современных экономических и социальных условий, влияющие на ее финансовое состояние. По уровню самооценки и степени социального признания семейный труд признан непрестижным и низко статусным, поэтому особо социально непривлекательным. Любой общественный труд оценивается и признается обществом в полной мере, при этом скрытая (умственная) часть семейного труда остается за пределами его признания. Следовательно, такие потребности, как общественное признание и высокий статус не может быть удовлетворены при помощи семьи.

Кроме того, молодые женщины стремятся к финансовой независимости, что обуславливает наличие ценностных ориентиров, связанных с карьерным ростом. Таким образом, изменяется величина ценности семьи в глазах молодых женщин, что оказывает серьезное влияние на выбор предпочтения карьеры перед созданием семьи.

В настоящее время современные молодые девушки с высшим образованием сознательно строящиеся свою будущую профессиональную стезю, не стремятся к раннему замужеству. Приобретение высшего образования является одной из ступеней в карьере и профессиональной самореализации. Достигнув желаемого статусного положения, они практически не тратят времени на личную жизнь. Уделять время семье при серьезной загруженности на работе для женщины не предоставляется возможным. У работающей женщины на домашние дела и решение семейных проблем не хватает ни физиологических, ни эмоциональных и психологических сил. Все свое время женщины, строящие карьеру, посвящают конкретной деятельности. 
Деловая женщина создает семью, лишь реализовав свои амбиции и достигнув определенного роста в профессиональной карьере и обретя стабильное материальное положение и высокий достаток. При этом, велика вероятность того, что ее партнером и по браку и по бизнесу может стать муж также вхожий в профессиональные круги. Подобные семьи нередко оказываются достаточно прочными. Каждый из супругов прилагает много усилий и времени работе и считает это нормой современного образа жизни. В браке деловых людей оба партнера принадлежат к одному социальному слою и экономически не зависят друг от друга. Следовательно, и конфликтов на почве делового взаимодействия у них не возникает, либо они имеют слабый характер, так как это может помешать их деловому сотрудничеству. А трудности в партнерской семье могут возникнуть, если сложатся обстоятельства, мешающие профессиональной деятельности.

В 2017 г. авторами было проведено исследование путем анкетирования через социальную сеть молодых женщин в возрасте 25-30 лет, проживающих в Москве и Санкт-Петербурге по проблемам выбора между материнством, созданием семьи и карьерными перспективами. Анализ данных позволил увидеть, что большинство женщин 25-27 лет, окончивших вуз недавно, в основном склоняются к выбору карьеры, а не семьи. В этом возрасте молодые женщины ориентированы на профессиональную состоятельность. Также можно отметить и то, что многие молодые стараются избежать проблем, связанных с семейной жизни. Это: жилищные вопросы, отсутствие помощи со стороны родительской семьи, социальнопсихологические проблемы совместного проживания с родителями, рождение детей, совмещение карьерных и семейных ролей (Социология молодежи, 2017: 246).

Опрошенные женщины с высшим образованием более старшего возраста (28-30 лет) чаще задумываются о необходимости создании семьи и в большей степени склоняются к выбору в пользу семьи порой в ущерб карьеры. (Похожие результаты подтверждают исследования С. В. Явон (Явон, 2012), Л. М. Кузьминой (Кузьмина, 2011), С. П. Лепчикова, Д. А. Данилова (Лепчикова, Данилова, 2017), В. И. Шиловской (Шиловская, 2010)). Это и понятно, что ближе к 30 годам не может не учитываться женщинами брачно репродуктивный период. Тем не менее следует отметить, что уровень образования молодых супругов не всегда положительным образом сказывается на репродуктивном поведении и ценности детей в молодой семье. Во-первых, возрастает «цена» времени, которое расходуется на детей, во-вторых, повышаются требования к качеству детей, их здоровью, образованию, воспитанию (Сердюченко, 2017: 252).

Современные реалии складываются таким образом, что женщина в обществе нередко стоит перед выбором: семья или карьера. Часто жен- 
щины работают потому, что им нужны деньги. Однако, как показывают социологические исследования, многие женщины, работающие из-за экономической необходимости, не бросили бы ее, даже если вдруг перестали бы нуждаться в деньгах. Как пишет Дойл, «деньги имеют не только материальную ценность, они дают их владельцу вес в обществе и чувство собственного достоинства» (цит. по: Багаутдинова, 2016: Электр. ресурс).

Таким образом, в современном обществе прослеживается тенденция изменения жизненных стратегий женщин в сторону профессионального самоопределения для успешной самореализации личности. Идеальная модель успешной жизни - сочетание двух важных ценностей семьи и профессиональной деятельности. Однако в современной жизни в конкурентных условиях возникают проблемы двойной занятости. Вопрос о выборе карьерных ориентаций или эффективной семейной жизни для российских женщин продолжает стоять остро.

\section{СПИСОК ЛИТЕРАТУРЫ}

Демография [Электронный ресурс] // Федеральная служба государственной статистики. URL: http://www.gks.ru/wps/wcm/connect/rosstat_ main/rosstat/ru/statistics/population/demography/\# (дата обращения: 12.08.2017).

Социология молодежи (2017): учебник / под ред. Р. В. Ленькова. М. : Юрайт. 246 с.

Багаутдинова, О. 3. (2016 ) Женщина перед выбором: семья или карьеpa? [Электронный ресурс]//Экономика и социум. № 3(22).URL: http://www. iupr.ru/domains_data/files/zurnal_22/Bagautdinova\%200.Z.Zhenshina\%20 pered\%20vyborom\%20semya\%20ili\%20karera.pdf (дата обращения: 12.08.2017).

Сердюченко, Я. В. (2017) Факторы формирования жизненного мира молодой семьи в Ростовской области // Государственное муниципальное управление. Ученые записки СКАГС. № 3. С. 249-253.

Явон, С. В. (2012) Жизненное самоопределение российской молодежи // Знание. Понимание. Умение. № 4. С. 174-178.

Кузьмина, Л. М. (2011) Модели жизненной стратегии молодой семьи по итогам социологического исследования // Научные ведомости Белгородского государственного университета. Серия: Философия. Социология. Право. № 8 (103). С. 223-228.

Лепчикова, С. П., Данилов, Д. А. (2017) Карьерный рост или семья в приоритете у современной женщины? // Научно-методический электронный журнал «Концепт». Т. 26. С. 261-263.

Шиловская, В.И.(2010) Работа или семья: социально-психологические факторы совладения женщин с жизненными стрессами // Вестник Ко- 
стромского государственного университета. Серия: Педагогика. Психология. Социокинетика. Т. 16. № 1. С. 181-186.

Дата поступления: 13.09.2017 2.

Ромашова Людмила Олеговна - кандидат социологических наук, доцент кафедры социологии Московского гуманитарного университета. Адрес: 111395, Россия, г. Москва, ул. Юности, д. 5. Тел.: +7 (499) 374-60-21. Эл. адрес: LOR7@yandex.ru

Середа Екатерина Михайловна - студентка факультета психологии, педагогики и социологии Московского гуманитарного университета. Адрес: 111395, Россия, г. Москва, ул. Юности, д. 5. Тел.: +7 (499) 374-37475-60. Эл. адрес: seredakatya2009@yandex.ru. Научный руководитель к.соц.н., доцент, Л. О. Ромашова.

Romashova Liudmila Olegovna, Candidate of Sociology, Associate Professor, Department of Sociology, Moscow University for the Humanities. Postal address: 5, Yunosti St., Moscow, Russian Federation 111395. Tel.: +7 (499) 374-60-21.E-mail: LOR7@yandex.ru

Sereda Ekaterina Mikhailovna, Student, Faculty of Psychology, Pedagogy and Sociology, Moscow University for the Humanities. Postal address: 5, Yunosti St., Moscow, Russian Federation 111395. Tel.: +7 (499) 374-374-75-60. E-mail: seredakatya2009@yandex.ru. Scientific Adviser - L. O. Romashova, Candidate of Sociology, Associate Professor.

\section{Для циитирования:}

Ромашова Л. О., Середа Е. М. Семья и карьера в жизни современной российской женщины [Электронный ресурс] // Научные труды Московского гуманитарного университета. 2017. № 5. URL: http://journals.mosgu. ru/trudy/article/view/565 DOI: 10.17805/trudy.2017.5.3 (дата обращения: дд.мМ.гг.). 